\title{
The journey of individuation: A Jungian alternative to the theory and practice of leading authentically
}

\author{
Ladkin, DM
}

http://hdl.handle.net/10026.1/10897

$10.1177 / 1742715016681942$

Leadership

SAGE Publications

All content in PEARL is protected by copyright law. Author manuscripts are made available in accordance with publisher policies. Please cite only the published version using the details provided on the item record or document. In the absence of an open licence (e.g. Creative Commons), permissions for further reuse of content should be sought from the publisher or author. 
AUTHENTICITY AND INDIVIDUATION: A JUNGIAN CONTRIBUTION TO THE THEORY AND PRACTICE OF LEADING AUTHENTICALLY

\author{
Donna Ladkin \\ Professor of Leadership and Ethics \\ Graduate School of Management, Plymouth University \\ Plymouth, UK \\ Donna.Ladkin@plymouth.ac.uk
}

Chellie Spiller

Senior Lecturer and Associate Dean Maori and Pacific

University of Auckland Business School

Auckland, NZ

C.Spiller@auckland.ac.nz

\author{
Gareth Craze \\ PhD Student \\ Organizational Behavior Department \\ Case Western Reserve University \\ Cleveland, Ohio, USA \\ $\underline{\text { Gareth.Craze@gmail.com }}$
}




\title{
AUTHENTICITY AND INDIVIDUATION: A JUNGIAN CONTRIBUTION TO THE THEORY AND PRACTICE OF LEADING AUTHENTICALLY
}

\begin{abstract}
Along with increasing interest from both leadership scholars and organizational members in the concept of 'authenticity' as it applies to leadership, critique of the dominant way in which authentic leadership is theorized is also on the rise. In particular, recent empirical accounts of individuals attempting to enact authentic leadership reveal the difficulties associated with doing so, especially in relation to current theorizing's emphasis on leaders' display of predominantly positive, pro-social behaviours. This paper enriches current theorizing by introducing Carl Jung's notion of 'individuation' as a journey through which shadow aspects of the self can be incorporated into, rather than dismissed from the act of leading. Such a construction develops current authentic leadership theorizing by 1) highlighting the limits of conscious decision making in relation to behavioural choices and recognizing the powerful influence the unconscious exerts on thoughts and actions, 2) proposing that authenticity is achieved through integrating less desirable aspects of the self rather than repressing them, and 3) appreciating the role of the collective in creating an authentic sense of self, rather than valorising individual self-knowing as authenticity's sole source. By enlarging the authentic leadership construct from this perspective, the paper provides a psychologically robust, if developmentally challenging, means by which those aspiring to bring something of their 'real' selves into their enactment of leading might do so.
\end{abstract}

Keywords: authentic leadership, individuation, Jung, psychodynamics of leadership, the shadow, the unconscious 


\section{AUTHENTICITY AND INDIVIDUATION: A JUNGIAN CONTRIBUTION TO THE THEORY AND PRACTICE OF LEADING AUTHENTICALLY}

Increasing interest in 'authenticity' and how it applies to leadership is apparent in both scholarly and practitioner based accounts of leadership (Avolio \& Walumbwa, 2014; Endrissat, Müller, \& Kaudela-Baum, 2007; Gardner, Cogliser, Davis, \& Dickens, 2011; George, 2003; Ladkin \& Spiller, 2013). A growing critique of the dominant way in which authentic leadership (AL) is theorized is also on the rise (Alvesson \& Sveningsson, 2013; Berkovich, 2014; Smolovic Jones \& Grint, 2013). In particular, recent empirical studies of individuals attempting to enact authentic leadership reveal the difficulties associated with doing so, especially in relation to current theorizing's emphasis on leaders' display of predominantly positive, pro-social behaviours. For instance, in reporting the experience of participants in a leadership development programme Nicholson and Carroll (2013) suggest that individuals pursuing this ideal can experience debilitating levels of frustration.

Similarly, a study by Nyberg and Sveningsson finds that, 'in contrast to the positive images portrayed in the authentic leadership literature, managers expressed that acting according to their "true self" promoted negative responses and made them feel bad' (2014, p. 438).

Our own experiences of working with organizational leaders in the developmental context is that they are often perplexed by the notion that they should turn to their 'true selves' when taking up the leader role. For many of them, the role requirements inherent to leading mean they can be anything but 'themselves' in enacting tough organizational decisions (especially when that self feels angry, unsure or disheartened). Studies such as Nicholson and Carroll's and Nyberg and Sveningsson's, as well as our own experiences within the leadership development space prompt us to question current theorizing of the concept. In particular, we 
ask if there is a way of conceptualizing authenticity and its relationship to leadership which allows for the imperfections inherent in the human condition? An understanding of the unconscious and the role it plays in human behaviour and development is offered as a vital component of such a conceptualization.

The writings of the psychologist Carl Jung are introduced in developing these ideas. Jung's work is singularly helpful in providing insight into the role unconscious aspects of character play in achieving fully-functioning maturity. In particular, his notion of 'individuation' provides a holistic account of the journey individuals can undertake in moving beyond enacting a mask, or 'persona' to forming a mature 'personality'. Although it is important to note that Jung himself did not refer to 'authenticity', there are resonances between his notion of individuation and a construction of authenticity based in 'self realisation' (Harter, 2002; Kernis, 2003). Jung's notions of 'the shadow', 'the centre point' and 'the collective' offer further depth to developing a construction of authentic leadership attuned to the power of the unconscious. In bringing these concepts to the notion of authentic leadership, the paper aims to provide those aspiring to lead from a sense of what is 'real' for them, as well as those aiming to develop such leaders, with a version of 'authenticity' which embraces the inherent tensions and paradoxes central to the experience of being human.

The paper is organized as follows: current AL theorizing is summarized and critiqued, particularly in relation to its silence concerning the unconscious and how it informs human behaviour. Broader understanding of the unconscious and its role within leadership and organizational processes is considered before focusing on Jung's work specifically. Jung's notion of the journey of individuation is introduced, and links are made between that process and the way in which the attainment of authenticity is theorized. We consider how the process of individuation enriches authentic leadership theorizing, focusing on three key dimensions of that problematization: 1) how an appreciation of the unconscious challenges 
rationally based versions of authentic leadership and its development which over-emphasize the possibilities of individual agency; 2) how a Jungian-informed perspective emphasises the need to integrate less desirable aspects of the self rather than dismissing them; and 3) how authenticity as individuation implies the journey towards authenticity is collectively constructed rather than individually attained. The paper ends by outlining the theoretical, as well as practical implications for a Jungian-informed rendering of authentic leadership.

\section{Authentic leadership and its critique}

The most frequently cited theoretical sources concerning authentic leadership are published by Bruce Avolio, William Gardner, Fred Luthans, Douglas May, and Fred Walumbwa in various combinations (see Gardner et al., 2011, p. 1028 for their analysis of authentic leadership citations up to 2011). In an attempt to provide an antidote to falling levels of trust in American political and corporate leaders in the early years of the new millennium, these scholars claimed authenticity as the watchword for effective leadership (Avolio et al., 2004; Avolio \& Gardner, 2005; Walumbwa, Avolio, Gardner, Wernsing, \& Peterson, 2008). Alert to the apparent burgeoning of positive leadership approaches, such as 'ethical leadership'(Ciulla, 2004) 'servant leadership' (Greenleaf \& Spears, 2002) and 'quiet leadership' (Badaracco, 2002); Avolio and his colleagues identified authenticity as the bedrock underpinning all such 'positive forms' of the phenomenon (Avolio, Gardner, Walumbwa, Luthans, \& May, 2004; Avolio \& Gardner, 2005). Theoretically, this was accomplished through associating authentic leadership with the positive organizational scholarship (POS)(Cameron, Dutton, \& Quinn, 2003) and positive organizational behaviour movements (POB) (Luthans, 2002). Indeed, among the descriptors for 'authentic leaders' key scholars in the field Avolio, Gardner, Walumbwa, Luthans and May include such positive attributions as 'confident, hopeful, optimistic, resilient and high in moral character' (2004, p. 4). 
United around the rallying call that authenticity in leadership is an unequivocally 'good thing', the notion has been elaborated to the level of a 'higher order construct' resulting from the combination of four sub-components: self awareness, relational transparency, balanced processing and moral perspective (Avolio \& Gardner, 2005). A self-report instrument, the Authentic Leadership Questionnaire (ALQ) has been formulated and validated (Walumbwa et al., 2008). There is a comprehensive research programme in play to test different aspects of authentic leadership and to predict organizational outcomes associated with authentic leading. Early results indicate positive associations; the presence of an authentic leader at the apex of an organization's hierarchy is reported to result in higher levels of employee engagement (Giallonardo, Wong, \& Iwasiw, 2010), greater levels of trust between managers and their subordinates (Clapp-Smith, Vogelgesang, \& Avery, 2009) and higher ethical standards throughout the organization (Hannah, Lester, \& Vogelgesang, 2005).

Underpinning Avolio et al's notion of the authentic self is the work of Harter (2002) and Kernis (2003) who equate authenticity with acting in accordance with one's 'true self'. Interestingly this 'true self' seems to exhibit wholly positive attributes as evidenced by Gardner et al's assertion that 'Authentic leaders are also posited to draw from the positive psychological states that accompany optimal self-esteem and psychological well-being, such as confidence, optimism, hope and resilience, to model and promote the development of these states in others' (Gardner, Avolio, Luthans, May, \& Walumbwa, 2005, p. 345). This focus on the positive echoes throughout their subsequent theorizing.

A point of interest within this account of authentic leadership is the assertion that authenticity is attained through two key processes: 'self awareness', and 'self regulation' (Avolio \& Gardner, 2005). Drawing from Silvia \& Duval (2001) they suggest that self awareness occurs 'when individuals are cognizant of their own existence, and what constitutes that existence within the context within which they operate over time (Avolio \& Gardner, 2005, p. 
324). Self regulation involves 'the processes whereby people exert self-control' (p. 325), especially in relation to discrepancies between desired behaviours and their values.

What is interesting about the notion of self regulation is that within it rests an unstated assumption that there are two selves; a regulating self and a self which needs regulating (Shaw, 2010). Which, one wonders, is the 'true self'? Avolio et al. indicate the self which regulates is the 'true self' and that this self engages rationally based discernment in aligning actions with values. We challenge this view and argue that a myriad of dynamics affects one's choice of actions, including those which are difficult to access through consciouslybased cognition. Furthermore, we suggest that all of these forces play a role in constituting what is experienced as one's 'self' ('true' or otherwise). A psycho-dynamically informed understanding of the self would indicate that it is through integration of the 'regulating self' and the 'self that requires regulating' that a sense of authenticity is achieved (Jung, 1993). Before pursuing that line of argument further, we turn to considering how dominant theorizing of authentic leadership has been critiqued by others.

\section{Enter the critique}

Discomfiture with contemporary AL theorizing is apparent in the literature and represents an aspect of broader concerns about the way leadership has been traditionally theorized. For instance authors such as Gemmill and Oakley (1992) refer to leadership as an 'alienating social myth', and Alvesson and Sveningsson (2003) assert it to be 'valorisation of the mundane'. Kelly $(2008,2014)$ goes as far as to suggest that traditional theorizing represents a 'categorical error' and needs to be reconceptualised from an ontological basis. Within critique of AL theorizing, Smolovic Jones and Grint (2013) echo Kelly's challenge in questioning the ontological basis of authenticity as it is applied to leadership, citing three difficulties: the veracity problem (the inherent impossibility of being 'true' to oneself when 
taking up a role such as leading which by its nature requires one to take others into account), the essentialist problem (the impossibility of there being one true self to which one can be authentic), and the normative problem (the extent to which contemporary AL theorizing amalgamates morality with authenticity, an issue also raised by Ladkin and Taylor, (2010) and empirically by Eilam-Shamir and Shamir, (2013). Indeed, it can be reasonably asserted that much AL theorizing is based on its intuitive appeal to generic notions of positivity that are grounded in little more than 'folk psychology' (Dennett, 1991).

Lawler and Ashman (2012) criticize Avolio et al's (2005) understanding of authenticity as being grounded in self-awareness. Drawing from existential philosophy (which they argue is much better placed to inform notions of 'authenticity' than the Greek philosophers to whom Harter (2002) refers) they suggest that any robust construction of authenticity should be 'rooted in the substantive principle of taking personal responsibility, not ephemeral ideas of self-awareness and integrity' (Lawler \& Ashman, 2012, p. 336).

Addressing questions of how authentic leadership might be enacted, Berkovich (2014) takes issue with dominant theorizing's neglect of the practical and political aspects of leadership in organizations. Indicative of our own uneasiness with this way of constructing authentic leadership, he writes 'At present, authentic leadership theory appears unwilling to acknowledge that pressures on leaders to be consistent with the dominating positive images of leadership can cause them to suppress or hide parts of their true (sic) selves.' (Berkovich, 2014, p. 246). Indeed Diddams and Chang (2012) suggest that the pressure on 'authentic' leaders to continually display positive behaviours can paradoxically lead to 'inauthentic' behaviour.

In a similar vein, Ford and Harding (2011) incorporate Jessica Benjamin's psychoanalytic approach to critique AL theorizing from an object-relations perspective. They argue that the 
subject at the centre of current AL thinking is 'inadequate' in that, 'it is a positive psychology perspective which refuses to acknowledge the rounded subject as someone full of contradictions' (p. 476). Furthermore, they suggest that such a formulation of the self can instigate 'psychological suffering', as it presumes the existence of individuals who are so lacking in any shortcomings they appear saintly (p. 470): 'There is no room, in this model, for self-knowledge to reveal anything that is not positive. The individual is not allowed a dark side' (p. 457).

Nyberg and Sveningsson's empirically based study supports Ford and Harding's prediction of psychological distress for those attempting to enact this wholly positive version of themselves. In their qualitatively-based study organizational leaders expressed disquiet with the way in which 'authenticity could backfire and portray them as bad leaders in terms of dominating others, being awful or forceful' (Nyberg \& Sveningsson, 2014, p.447). Nyberg and Sveningsson's findings are echoed in the case study of 'Annie' presented by Nicholson and Carroll (2013). A participant in a leadership development programme, Annie's blog while undergoing the programme represents her as 'near breaking point' as she attempts to constantly 'better herself' in the service of becoming ever more 'authentic'.

These empirically based accounts pique our curiosity about how authenticity might be enacted within leadership relations, given the contradictory nature of the self, as well as the political demands of the contexts in which individuals take up the leader role. Is there a different way of understanding the self in all of its complexity, which might enrich current AL theorizing? Again we note the wholly rational basis of dominant theorizing which easily dismisses the darker, hidden and complex motives which inform most human action (let alone the actions of those in leadership roles). In order to consider what is already known about the role of the unconscious in organizational setting, the next section of the article briefly reviews key understandings. 


\section{The Unconscious in organizational and leadership theorizing}

Kets de Vries and Cheak (2014) provide a helpful overview of the history of how psychodynamics has been used within organizational theory. Spearheaded by research undertaken in four key institutions (The Tavistock Institute in London, the Menninger Clinic in Topeka, Kansas, Harvard Business School and Cornell Medical School), the role of psychodynamic processes, and particularly the way in which unconscious processes can affect how organizations work has been explored in a range of public and private sector settings. A comprehensive analysis of the various (and often conflicting and contrasting) schools of thought which continue to colour the landscape of this avenue of scholarly enquiry are beyond the scope of the present paper. However, it is important to establish an operational definition of the unconscious before exploring its relationship to leadership in organizations.

Freud (1915)described three levels of mind by using the analogy of an iceberg: conscious, preconscious and unconscious. Conscious is the tip of the iceberg, preconscious just below the surface and the unconscious forming its submerged bulk. The unconscious is comprised of repressed memories that may be too painful to acknowledge and our instincts which may be deemed unacceptable to our sense of ourselves and society. More recently the notion of adaptive unconscious (Wilson, 2004) highlights that the unconscious is also the repository of processes for reasons of efficiency, such as enacting certain procedures.

In their Special Issue of Human Relations dedicated to the subject, Neumann and Hirshhorn (1999) review ways in which the unconscious and its dynamics influence organizational life. Since their Special Issue further theoretical and empirical work has been undertaken which demonstrates the difficulties which arise when the unconscious is neglected or not woven into the conception of the self. These include: the problems that occur when the shadow self is inadequately addressed when dealing with organizational conflict and the possibility of 
unconsciously triggering counter-reactionary responses (Hede, 2007; Ketola, 2012) the transfer (and distribution of cognitive strain) of less desirable characteristics of the shadow from the individual to the organization (Cilliers \& Terblanche, 2010); the organizational malaise that sets in when these shadow characteristics are as obscured and neglected at the organizational level as they were at the collective level (Fawkes, 2009); and the potential for corruption (Khoo \& Burch, 2008), burnout (de Toit, Veldsman, \& van Zyl, 2011), and disconnection between leader rhetoric and operational reality (Kets de Vries, 2005).

In contrast to the deleterious consequences of not recognizing and addressing unconscious aspects of the self, a substantial body of work highlights the tremendous power for solving problems in organizations that arise when the leader's unconscious is more fulsomely understood and embraced. Ketola (2012) has argued that leaders suitably attuned to the full sphere of their spectrum of consciousness exhibit greater responsibility in organizational contexts while also behaving with greater authenticity and less pretence. A number of scholars (see e.g. Branson, 2007; Rozuel \& Kakabadse, 2010; Sanders, Hopkins, \& Geroy, 2003; Young, 2002) have outlined the significantly positive effects on organizational-moral leadership dimensions (including not only more moral treatment of subordinates, but a more intuitive feel for understanding and improving an organization's moral compass) which arise from leaders attending to their unconscious selves and the various shadowy characteristics therein.

Young (2002) and Figler and Hanlon (2008) argue that leaders who habitually and critically self-reflect with the intention of embracing the totality of their consciousness, demonstrate more expertly-honed faculties in the arenas of problem solving and decision making under critical or otherwise stressful circumstances. Further, leaders who evince a desire and willingness to critically self-reflect have been shown to develop a greater sense of trustworthiness among other actors in the organizational setting (Bjursell \& Larsson, 2008; 
Dolbier, Soderstrom, \& Steinhardt, 2001) Finally, Cilliers and Terblanche (2010) and Poutiatine (2009) have illustrated the beneficial effects leaders experience when, having previously cleaved and compartmentalized their conscious and unconscious selves, they pursue a course of integration of these strata of consciousness. This notion of the need for alignment among various strata of consciousness echoes Jung's theory of individuation which is elaborated in the next section of the paper.

Before turning to that however, it is interesting to note that to date, those considering the role of the unconscious within organizations and leadership have paid scant attention to authentic leadership. Given the centrality of the notion of the self to authentic leadership theorizing, exploring theories of how the self develops into a differentiated individual seems vital. Carl Jung's work is introduced to address this omission, largely because his understandings of the complexities involved in integrating conscious and unconscious aspects of the self in the service of becoming a mature personality offer heretofore unexplored insights into the journey toward authentic selfhood.

\section{Carl Jung and his theory of individuation}

Along with Sigmund Freud, the Swiss-born psychologist Carl Jung (1875-1961) is recognized as one of the key founders of psycho-analytic theory. Perhaps best known in managerial circles for his theory of personality (1967) which provides the theoretical foundation for the Myers Briggs Type Indicator, Jung's work is foundational for current psychological understanding of the unconscious, the collective unconscious and the role of archetypes in human development.

Jung posits that 'almost half our life is passed in a more or less unconscious state' (Jung, 1974, p. 318) and encourages knowing our particular 'earthly and unearthly darknesses' (Jung, 1956, p. 124). However, many people, he believes, in their urge to being 'convinced of 
an absolute good' are bidden to 'listen to the voice of those who espouse the superiority of consciousness and unambiguous thinking' (Jung, 1956, p. 125). Ideologies, notes Jung, have the power to romanticize some aspects of human psychology while demonising others (Jung, 1957). We contend, that the positive stance taken in much AL theorizing has veered into an ideology of the positive; an unambiguous superiority of that which is deemed 'good', but which in practice is impossible, and possibly not desirable, for those leading organizations to aspire to enact.

\section{Individuation}

As noted earlier, Jung himself did not write about 'authenticity'. During the time he was developing his theory of personality, others such as Carl Rogers (2012) and Abraham Maslow (1950) were formulating theories of 'self actualization', and Jung's language echoes their discourse. Jung used the terms 'persona', or 'mask', to indicate the mode through which human beings engage with one another in social relations. He characterized the development of the mature individual as moving from the 'persona' to the 'personality', which is won through the process of individuation.

According to Jung, individuation is the process of 'self realization' (Jung, 1993) which he characterizes as a 'law of nature' (Jacobi, 1965). Jolande Jacobi's book, The Way of Individuation provides a clear guide through Jung's thinking on the subject. She argues that Jung's notion of individuation 'takes account not only of the conscious but also of the unconscious components of the psyche in their delicately balanced and creative interaction with the conscious mind' (ibid, p. 13). Jacobi's work in which the notion of individuation offers an important integrative bridge for authentic leadership theorizing and development.

For instance, both emphasize the importance of the expression of something which is central to the experience of the self. Both recognize the existence of different aspects of the self (for 
instance, AL theorizing identifies 'the self' and the 'regulating self', Jung recognizes different attitudes as represented by the different cognitive functions of consciousness). Both identify the psychic importance (for both the individual and those around her or him) for something of what is experienced as real about the individual to be apparent.

There are also significant differences in the way the two ideas are constructed. For Jung, the individuation process requires the integration of conscious and unconscious aspects of the self which can allow for a 'third', unexpected way of operating to emerge. Jung outlines particular phases of the individuation project and stresses that the process is 'not linear', but instead, 'consists of progress and regress, flux and stagnation in alternating sequence' (Jacobi, 1965 p. 34). During the first half of life, the job of individuation is indeed to develop the 'persona', the public 'face' which enables the self to be known in a relatively stable way. Trouble develops however if the individual identifies solely with this 'persona'. During the second half of one's life, the job of individuation is to reclaim and develop those aspects of the self which have not been developed or which have been suppressed. This move to coming to one's self-hood may, at first blush, appear to echo AL theorizing inasmuch as authentic leadership involves discovery of that which is authentically individual. However, where contemporary theorization constructs the authentic self by way of four positive components (self awareness, relational transparency, balanced processing and moral perspective) a Jungian approach emphasizes the process of 'individuation' which embraces all aspects of the self, not only the positive ones.

Individuation does not result in mediocrity where nothing in particular about the self stands out, rather, 'individuation means becoming a single, homogenous being, and, in so far as “individuality" embraces our innermost, last, and incomparable uniqueness, it also implies becoming one's own self' (Jung, 1993, p. 181). This has strong resonances with the quest 
towards having a sense of one's 'authentic' self. However, rather than being achieved through rationally developing self awareness, relational transparency, balanced processing and moral behaviour (Avolio \& Gardner, 2005) the journey of self-discovery, says Jung (1993), requires 'profound reflection' and when we do so we 'realize how commonly difficult the discovery of individuation in fact is' (p. 172).

A key difference between this notion of individuation and dominant AL theorizing's construction of authenticity is the importance Jung places on integrating less desirable aspects of the self in a way which enables the 'owning of our own shadow' (Johnson, 1991). Unless this happens, true self-hood is not reached. Given its centrality to the Jung's thinking the notion of the shadow is elaborated below.

\section{The shadow}

According to Jung the shadow is comprised of those personal and collective psychic elements deemed inferior: 'because of their incompatibility with the chosen conscious attitude, [they] are denied expression in life and therefore coalesce into a relatively autonomous 'splinter personality' with contrary tendencies in the unconscious' (Jung, 1989, pp. 398-399). As part of the unconscious, the shadow is often cast as the 'despised quarter of our being' that sometimes 'erupts as an overpowering rage or some indiscretion that slips past us; or we have a depression or an accident that seems to have its own purpose' (Johnson, 1991, pp. 4-5). The poet Robert Bly describes the shadow as 'the long bag we drag behind us' (1988, p. 17) into which we put, from childhood onwards, those parts of ourselves that parents, teachers and others do not approve of. Many of us are taught to supress our shadow, stow it away where no-one can see it. This tendency is apparent in AL theorizing which focuses wholly on the positive expression of the self without allowing room for the 'self-centred', 'fearful', 'envious', or 'irritable' aspects which are part and parcel of us all (see for instance Avolio, Gardner, et al., 2004). 
Try as we might to illuminate only the bright side of ourselves, such efforts, however, will not eradicate our shadow. Indeed the repressed dark side will only amass more and more energy, building up to the point where it needs to be released in some way. Johnson (1991) explains this by suggesting, 'We must be whole whether we like it or not; the only choice is whether we will incorporate the shadow consciously and with some dignity or do it through some neurotic behaviour' (pp. 26-27). The unrecognized, unaddressed stowaway shadow will simply find a way to break out. When this occurs it may wreak havoc in a far more terrible way than had we dealt with it along the way. As Johnson warns, 'The shadow gone autonomous is a terrible monster in our psychic house' (Johnson, 1991, pp. 4-5). The shadow may leak out in small acts of passive aggression, a malingering malaise, psychosomatic illness or even a burning resentment that can lead us to take positions of entrenched intolerance.

A psychodynamic approach appreciates that shadow aspects are present in us all. Jung writes convincingly that the normative pressures to ignore the shadow can create an even greater likelihood of its emergence in the un-integrated form of psychopathic tendencies. Left unacknowledged these tendencies can erupt into the kind of dysfunctional behaviour noted in Boddy's (2011) study of corporate psychopaths whose dark leadership, lack of conscience, absence of empathy for and ruthless manipulation of others has been a recipe for corporate and social disaster. In the context of the present inquiry, dominant AL's roots in positive organizational studies, positive organizational behaviour, and positive psychology can push aspiring authentic leaders to the bright end of a 'see-saw' and in doing so land them on psychically unstable ground.

To be whole, the self must turn its attention towards its shadow, not in an obsessive, navel gazing fashion, but to bring awareness to dark thoughts and impulses which are often hidden from the self and others. Try as we might, however, even so-called conscious moments are 
entangled with unconscious dynamics which include 'shadowy' elements (Jung, 1967, 1970). Jung (1957) suggests that the freedom and autonomy of the individual depend on a direct knowing and experiencing of the self in all its manifestations and exhorts individuals to pursue deep self-reflection as a means to reconciling potential destructive capacities and inner emptiness. This work takes place 'in the centre point', a notion described next.

\section{The centre point}

Jung (1968) used the mandala as a symbol for the "concentric arrangement of the disordered multiplicity and of contradictory and irreconcilable elements' (p. 388) that comprises the human psyche. To varying degrees everyone's psyche is a multifaceted churn of reactions, emotions, preoccupations, fears and other elements that can lead to a sense of disorder and imbalance. Yet, Jung argued that at the centre of this maelstrom we have constructed a central point from which all else emerges.

Johnson (1991) likens the centre point to 'the middle ground' at the centre of a seesaw. At the centre there is no longer straining to be at the bright end, nor sliding with a thump to the opposite, or swinging wildly from one to the other. Rather, standing in the middle ground enables discerning awareness of the opposing, sometimes colliding elements within. Jung argued the realized self is 'absolutely paradoxical in that it represents in every respect thesis and antithesis, and at the same time synthesis' (Jung, 1993, p. 558).

The centre of the see-saw is not a bland and boring place of compromise and concession, stripped of meaning and passion. Rather, Jung suggests that the centre is the wellspring of purpose, meaning and joy (Jung, 1993). Jacoby (2000) explains that Jung's conception of the self 'is the centre of the personality as a whole, including its conscious and unconscious parts' (p. 491). Such a conception differs from the more common 'self as self-representation, i.e.; the way I see myself' whereby the ego takes on the task of discovering and experiencing 
the self. The self as self-representation is akin to kind of fool's gold, as 'the ego can know only that part of our personality that is consciously accessible' (Jacoby, 2000, p. 493). In other words, seeking consciously to be authentic, and positive to boot, leads almost inevitably to not being authentic as the ego is the sole architect of this version of 'authenticity'. A Jungian-informed view of authenticity recognizes the need to acknowledge and involve all aspects of the self, lest they leak out in unhelpful or even destructive ways.

\section{The role of the collective}

Jungian theorizing is striking in that although it is focussed on the individual self and how that self achieves wholeness, that wholeness is always attained through engagement with the collective. Self-actualization is achieved in relationship or what Jung (1946) called 'kinship libido' (p. 224), Jacoby (2000) highlights that Jung was apt to say that 'that no one can individuate on the Mount Everest' (p. 492).

In many contemporary Western societies, 'authenticity' is colloquially equated with being original, unique and even peculiar and idiosyncratic (witness the common view that the current candidate for the USA's Republican presidential nomination, Donald Trump, is authentic). Being true to such an individualized self often means wanting to stand in isolation from the collective. Yet, says Jung, this is where thinking about what constitutes becoming a mature individual can go awry. 'Individuation means precisely the better and more complete fulfilment of the collective qualities of the human being, since adequate consideration of the peculiarity of the individual is more conducive to better social achievement than when the peculiarity is neglected or suppressed' (Jung, 1993, p. 182). In other words, in neglecting aspects of the self which are collectively attuned in favour of valorising our peculiar brand of individualism, a part of the self that finds fulfilment and self-hood with others is suppressed. Interestingly, Harter's (2002) more complete definition of authenticity takes into account the 
notion that the authentic self is only created through interactions with others, an insight which is largely overlooked in dominant AL theorizing.

Jung highlights how attempts at being individualized in this way can paradoxically thwart the unfolding of an individual's true potential. He writes: 'The individual is not just a single, separate being, but by his (sic) existence presupposes a collective relationship, it follows that the process of individuation must lead to more intense and broader collective relationships and not to isolation' (Jung, 1993, p. 172). This differs from the thread of thinking within dominant AL theorizing which emphasizes the 'solo' nature of authenticity based on 'self awareness' ( Avolio, Luthans, \& Walumbwa, 2004).

In summary, we propose that these aspects of Jung's theory of individuation can enrich dominant AL theorizing in three ways: 1) Jung's understanding of the unconscious and the role it plays in individuation provides a complex view of the journey towards authenticity which challenges the extent to which authenticity can be attained through conscious processes alone; 2) Jung's notions of the 'shadow' and the 'centre point' suggest authenticity is achieved through integrating, rather than dismissing or ignoring undesirable aspects of the self; and 3) the role of the collective emphasizes that authenticity is not achieved through a solo journey but through consideration of what is optimal to promote the flourishing of the collective. Each of these points is elaborated in the discussion, below.

\section{Discussion}

The journey towards authenticity as involving unconscious, as well as conscious dynamics

Perhaps the most fundamental challenge to dominant AL theorizing offered here questions the extent to which authenticity is achieved through rationally-based, conscious processes. A Jungian standpoint invites recognition of unconscious dynamics and how they influence the 
choices we make. Indeed, an appreciation of the role of the unconscious suggests that choices which are experienced as rationally derived made may be anything but!

Even intentions, such as that to be 'positive', rest on an unconscious background, where consciousness appears only as the intermittent functioning of an unconscious psyche. AL theorizing, and particularly the exhortation to wilfully engage only positive dimensions of the psyche, implies a faculty of conscious control of cognitive processes which runs counter to any appreciation of the power of the unconscious. Psycho-analytic theory suggests that the sphere of control one possesses in choosing to become authentic through a rational process is limited, if not non-existent.

We propose there are practical steps that leaders can take in attending to the unconscious, and in fashioning a sense of authenticity aligned with the process of individuation by:

- Noticing and dwelling with actual feelings, emotions and reactions and exploring them rather than immediately putting on a brave face, or one's leadership face;

- Attending to intuitions, vague or strong reactions, dreams, and recording these through mechanisms such as journaling or keeping a diary;

- Expecting contradictions and paradox and exploring these tensions, rather than dismissing them.

Authenticity is achieved through integration rather than dismissing or ignoring

Over focussing on the positive, idealized self has the potential to create an imbalance and severance in the psyche. Theoretically this means AL needs to be informed by psychological theories which recognise wholeness, maturation processes, and ongoing, dynamic aspects of the self rather than static, measureable components. The movement away from prescriptive and reductionist recipes affirms Jung's belief that 'the psyche, consisting of the totality of 
conscious and unconscious processes, is able to regulate itself-seek and maintain a certain balance (Jacoby, 2000, p. 490).

The journey towards authenticity as an unconscious and conscious process of individuation highlights the importance of leaders accepting that acting authentically does not equate with always acting in a positive manner. Individuation requires courage in becoming more aware of unconscious and shadowy elements and how they influence even the best of intentions. A critical insight from Jung's notion of individuation for any leader aspiring to bring authenticity to their practice is that being 'real' does not mean being perfect. As Ladkin and Taylor (2010) point out in their paper concerning the embodied experience of authenticity, theatrical performances which are experienced as 'real', include a bit of 'the bad side' of a character; as 'totally saintly' characters are not believable.

Practically, from this perspective the leader aspiring to bring authenticity to their enactment would work to become aware of the inner dialogues which represent opposing desires and motivations when faced with choices of behaviour or judgements. Bringing greater awareness to all aspects of the self through critical reflexivity and working with (rather than ignoring) such inner would be essential. In this way, the process is not one of 'the regulating self' dismissing aspects of the self which do not align with values, but the fostering of inner conversations in which differing voices contribute to subsequent action. Of course this process is not as easy as this instruction suggests, and there are limits to the extent to which the unconscious can be accessed and worked with in this way. The important insight individuation provides the leader wanting to act from a place of authenticity is that less desirable aspects of the self have an important role to play, rather than being automatically discounted. Practically, this might also include the need for leaders to: 
- Accept failures in response to challenging situations and see them as a learning opportunities, rather than catastrophes;

- Undertake a more formal relationship with a professional in one of the fields of psychological work;

- Read and study key texts such as those that discuss Jung's work (Robert Johnson provides easily accessible explanations for the lay person), transactional analysis and object relations theory;

- Access processes to work on issues as they emerge, such as downloading Cognitive Behaviour Therapy (CBT) templates.

Importantly, engaging with less desirable aspects of the self does not provide permission for those holding leader roles to 'act out'. However, it does suggest the need to give such aspects psychic space to be recognized and creatively incorporated into leadership enactment.

Authenticity as a collective, rather than 'solo' achievement

Becoming a 'whole personality', according to Jung, is not solely, nor primarily, for the individual's benefit. A key tenet of Jung's notion is that the journey towards individuation is for the collective flourishing of humans, rather than solely for individual gain. Furthermore, according to Jung the process of individuation itself is always undertaken in community, not by the individual acting in social isolation. This view differs significantly from that apparent in dominant AL theorizing, in which authenticity is achieved through the individual communing primarily with his or her 'true self'. Indeed, popular writers such as Bill George (2003) suggest that turning to others can constitute an inauthentic response on the part of leaders. The difference between the AL perspective and that of Jung hints at the question of 'who is authenticity (or individuation) on the part of leaders for?' 
Interestingly, dominant AL theorizing includes having a 'moral perspective' as one of its four key components. That sense of morality however seems to stem primarily from the individual's own moral compass (as values play such a key role in AL theorizing). The Jungian view provides an alternative source of moral deliberation; in accordance with that which best fosters the flourishing of the human community of which the individualizing person is part. The distinction is perhaps subtle, but points to an important aspect of Jung's theorizing: its involving a sense of 'the journey of human kind as a whole' rather than being solely preoccupied with the individual psyche.

There are interesting resonances between Jung's notion of individualization based in community and those who see authentic leadership as the platform for 'authentic followership'(Algera \& Lips-Wiersma, 2012; Gardner et al., 2005). The positions differ however in that these scholars see the individual leaders as catalysing authentic relations, whereas Jung's theory of individuation is clear about the initiating role of the collective in initiating and supporting the journey towards individuation.

Practically, rather than referring solely to the 'inner self' when trying to navigate authentic enactment of the leader role, Jung's ideas would invite leaders to cultivate conversation with the communities they serve in creating an 'authentic' way forward. This could potentially involve professionally mediated feedback circles whereby a workplace community offer feedback to each other to advance the collective individuation journey. Some programmes, such as Immunity to Change by Kegan and Lahey (2009) offer team-based processes, and their recent book An Everyone Culture: Becoming a Deliberately Developmental Organization (Kegan, Lahey, Miller, Fleming, \& Helsing, 2016) takes an organizational level approach that actively seeks to develop every person in an organization and draws upon a number of psychologically informed practices. The Arbinger Institute (Arbinger Institute, 2010)is another example of an organization offering programmes for individuals, teams and 
whole organizations to get 'out of the box' of self-deception. They support leaders and their teams to see how they can be blinded to the own behaviour which distorts how they see each other and situations.

The following table summarises the theoretical and practical implications for a Jungianinformed rendering of authentic leadership.

\section{Insert Table 1 Here}

\section{Future Directions for a Jungian-informed Rendering of Authentic Leadership}

As indicated by the Table above, a Jungian-informed rendering of authenticity as it applies to leadership has important implications for both those taking up leader roles and those who aspire to help develop authentic leaders. Perhaps the most salutatory consequence concerns the likelihood of leaders unconsciously 'acting out' their dismissed or suppressed shadow aspects. The risk is that by ignoring less desirable aspects of the self, those taking up the leader role may inadvertently contribute to destructive organizational practices in unconscious ways. Rather than exhorting the creation of an ever-positive persona, leadership developers are urged instead to assist would-be leaders in identifying, acknowledging and finding ways of integrating these aspects of the self.

A number of further implications arise from this analysis for those aiming to develop authentic leaders. Perhaps most importantly, a Jungian-informed view suggests that such development is a long-term process rather than offering a 'quick-fix' approach.

Developmental activities which enable critical reflection on action and foster inquiry into assumptions as well as (unconscious) motives are essential. Creating safe spaces in which aspiring authentic leaders can explore their emotional responses is also vital, as is engagement with methods which evoke the expression of the unconscious, such as arts-based methods (Springborg, 2012). Finally, these suggestions imply the need for those aspiring to 
develop authentic leaders, to themselves be secure in working with uncomfortable emotional states and the ways in which the unconscious reveals itself.

Although research into the psychodynamics of leading continues to be championed by those such as Manfred Kets de Vries (see Coutu, 2004; Kets de Vries, 2003) further research is needed into how these ideas might contribute to the development of leaders who approach authenticity from this more holistic (and we would argue, realistic) perspective. Do individuals find the possibility of integrating, rather than dismissing, shadowy aspects from their enactment of leading helpful, or rather more daunting still? To what extent can psychotherapeutic processes be helpful in developing these capacities in organizational members? How do followers experience leaders who work with the tensions inherent in taking up their role in this way? Do they find it liberating, or more confusing? Does the new vogue for 'mindfulness practices' suggest practical ways in which less desirable aspects of individuals' psyche can be identified and integrated into enactment of the leader role? Would there be the possibility of conducting in-depth work with individuals committed to the journey of individuation as they take up leader roles, to discover their experiences and strategies for bringing their sense of a whole self into the workplace? These are all rich areas for further research into the application of Jung's ideas to approaching authenticity within the leader role.

Although conceptually derived, we hope the ideas presented in this paper provide helpful insights to those aspiring to take up leader roles in ways that allow for the wholeness of their experience to shine through. It is that 'wholeness', as Jung describes in his allusion to the mandala, which represents the most fulsome account of authenticity available to those taking up the challenging role of leading others. 


\section{References}

Algera, P. M., \& Lips-Wiersma, M. (2012). Radical Authentic Leadership: Co-creating the conditions under which all members of the organization can be authentic. Leadership Quarterly, 23(1), 118-131.

Alvesson, M., \& Sveningsson, S. (2003). Managers Doing Leadership: The ExtraOrdinarization of the Mundane. Human Relations, 56(12), 1435-1459.

Alvesson, M., \& Sveningsson, S. (2013). Authentic leadership critically reviewed. In D. Ladkin \& C. Spiller (Eds.), Authentic Leadership: Clashes, Convergences and Coalescences (pp. 39-54). Cheltenham, UK.: Edward Elgar.

Arbinger Institute. (2010). Leadership and Self Deception: Getting Out of the Box. San Francisco: Berrett-Koehler.

Avolio, B. J., \& Gardner, W. L. (2005). Authentic leadership development: Getting to the root of positive forms of leadership. The Leadership Quarterly, 16(3), 315-338.

Avolio, B. J., Gardner, W. L., Walumbwa, F. O., Luthans, F., \& May, D. R. (2004). Unlocking the mask: A look at the process by which authentic leaders impact follower attitudes and behaviors. Leadership Quarterly, 15(6), 801-823.

Avolio, B. J., Luthans, F., \& Walumbwa, F. O. (2004). Authentic leadership: Theory-building for veritable sustained performance. Lincoln: Gallup Leadership Institute.

Avolio, B. J., \& Walumbwa, F. O. (2014). Authentic leadership theory, research and practice: Steps taken and steps that remain. In D. Day (Ed.), The Oxford Handbook of Leadership and Organizations (pp. 331-356). Oxford: Oxford University Press.

Badaracco, J. (2002). Leading Quietly: An Unorthodox Guide to Doing the Right Thing. 
Boston, MA: Harvard Business School Press.

Berkovich, I. (2014). Between person and person: Dialogical pedagogy in authentic leadership development. Academy of Management Learning and Education, 13(2), 245-

Bjursell, C., \& Larsson, A. (2008). The Yin and Yang of organization: Applying Jung's terminology to take a closer look at management of shadows. http://www.divaportal.org/smash/record.jsf?pid=diva2\%3A36551\&dswid=5868

Boddy, C. (2011). Corporate Psychopaths: Organizational Destroyers. New York: Palgrave MacMillan.

Branson, C. M. (2007). Improving leadership by nurturing moral consciousness through structured self reflection. Journal of Educational Administration, 45(4), 471-495.

Cameron, K. S., Dutton, J. E., \& Quinn, R. E. (2003). Positive Organizational Scholarship. San Francisco: Berrett-Koehler.

Cilliers, F., \& Terblanche, L. (2010). The Systems psychodynamic leadership coaching experiences of nursing managers: original research. Health SA Gesondheid, 15(1), 1-9.

Ciulla, J. B. (2004). Ethics, the Heart of Leadership. London: Praeger.

Clapp-Smith, R., Vogelgesang, G., \& Avery, J. (2009). Authentic leadership and positive psychological capital: The mediating role of trust at the group level of analysis. Journal of Leadership and Organizational Studies, 227-240.

Coutu, D. L. (2004). Putting leaders on the couch: A Conversation with Manfred F. R. Kets de Vries. Harvard Business Review, 82(1), 64-71+113.

de Toit, D., Veldsman, T., \& van Zyl, D. (2011). The Testing and validatin of a model for leadership maturity based on Jung's concept of individuation. Sophia-Antipolis, France. 
Dennett, D. C. (1991). Real patterns. The Journal of Philosophy, 27-51.

Diddams, M., \& Chang, G. C. (2012). Only human: Exploring the nature of weakness in authentic leadership. Leadership Quarterly, 23(3), 593-603.

Dolbier, C. L., Soderstrom, M., \& Steinhardt, M. (2001). The Relationships between selfleadership and enhanced psychological health, and work outcomes. The Journal of Psychology, 135(5), 469-485.

Eilam-Shamir, G., \& Shamir, B. (2013). Life stories, personal ambitions and authenticity: Can leaders be authentic without pursuing a "higher good"? In D. Ladkin \& C. Spiller (Eds.), Authentic Leadership: Clashes, Convergences and Coalescences (pp. 93-119). Cheltenham, UK.: Edward Elgar.

Endrissat, N., Müller, W. R., \& Kaudela-Baum, S. (2007). En Route to an empirically-based understanding of authentic leadership. European Management Journal, 25(3), 207-220.

Fawkes, J. (2009). Integrating the shadow : A Jungian approach to professional ethics in. Ethical Space-International Journal of Communication Ethics, 6(2), 30-39.

Figler, R., \& Hanion, S. (2008). Management development and the unconscious from an analytical psychology framework. Journal of Management Development, 27(6), 613630.

Ford, J., \& Harding, N. (2011). The impossibility of the "true self" of authentic leadership. Leadership, 7(4), 463-479.

Freud, S. (1915). The Unconscious. SE, 14, 159-204.

Gardner, W. L., Avolio, B. J., Luthans, F., May, D. R., \& Walumbwa, F. (2005). Can you see the real me? A self-based model of authentic leader and follower development. The 
Leadership Quarterly, 16, 343-372.

Gardner, W. L., Cogliser, C. C., Davis, K. M., \& Dickens, M. P. (2011). Authentic leadership : A review of the literature and research agenda. The Leadership Quarterly, 22(6), 1120-1145.

Gemmill, G., \& Oakley, J. (1992). Leadership: An Alienating social myth? Human Relations, 45(2), 113-129.

George, B. (2003). Authentic Leadership: Rediscovering the Secrets to Creating Lasting Value. San Francisco: Jossey-Bass.

Giallonardo, L. M., Wong, C. A., \& Iwasiw, C. L. (2010). Authentic leadership of preceptors: Predictor of new graduate nurses' work engagement and job satisfaction. Journal of Nursing Management, 18, 993-1003.

Greenleaf, R., \& Spears, L. (2002). Servant Leadership: A Journey into the Nature of Legitimate Power and Greatness. Mahwah, N.J.: Paulist Press.

Hannah, S. T., Lester, P. B., \& Vogelgesang, G. R. (2005). Moral leadership: Explicating the moral component of authentic leadership. In W. B. Gardner, B. J. Avolio, \& F. O. Walumbwa (Eds.), Authentic Leadership Theory and Practice: Origins, effects, and development. Monographs in leadership and management. (pp. 43-82). Oxford: Elsevier/JAI Press.

Harter, S. (2002). Authenticity. In C. R. Snyder \& S. J. Lopez (Eds.), Handbook of Positive Psychology (pp. 382-394). London: Oxford University Press.

Hede, A. (2007). The Shadow group: Towards an explanation of interpersonal conflict in work groups. Journal of Managerial Psychology, 22(1), 25-39. 
Jacobi, J. (1965). The Way of Individuation. (R. F. C. Hall, Ed.). New York: New American Library.

Jacoby, M. (2000). The Growing convergence of contemporary psychoanalysis and Jungian analysis. Psychoanalytic Dialogues: The International Journal of Relational Perspectives, 10(3), 489-503.

Johnson, R. A. (1991). Owning your own shadow. New York: HarperCollins.

Jung, C. G. (1946). The Psychology of the Transference (Collected .). Princeton, N.J.: Princeton University Press.

Jung, C. G. (1956). Mysterium Conjunctionis: An inquiry into the separation and synthesis of psychic opposites in alchemy (2nd ed.). London: Routledge.

Jung, C. G. (1957). The Undiscovered Self (Present and Future) (1959 ed.). New York: Bollingen.

Jung, C. G. (1967). The Development of Personality (1991 ed. C.). London: Routledge.

Jung, C. G. (1970). Mother, Rebirth, Spirit, Trickster. ( trans. R. Hull, Ed.). Princeton, N.J.: Bollingen.

Jung, C. G. (1974). Dreams (Compilatio.). Princeton, N.J.: Princeton University Press.

Jung, C. G. (1989). Memories, Dreams, Reflections. New York: Random House.

Jung, C. G. (1993). The Basic Writings of C.G.Jung. New York: The Modern Library.

Kegan, R., \& Lahey, L. L. (2009). Immunity to Change: How to Overcome it and Unlock Potential in Yourself and Your Organization. Cambridge MA: Harvard Business School Press. 
Kegan, R., Lahey, L. L., Miller, M., Fleming, A., \& Helsing, D. (2016). An Everyone Culture: Becoming a Deliberately Developmental Organization. Cambridge MA: Harvard Business School Press.

Kelly, S. (2008). Leadership: A categorical mistake? Human Relations, 61(6), 763-782.

Kelly, S. (2014). Towards a negative ontology of leadership. Human Relations, 67(8), 905-

Kernis, M. H. (2003). Toward a conceptualization of optimal self-esteem. Psychological Inquiry, 14(1), 1-26.

Ketola, T. (2012). Losing your self: managerial persona and shadow pressures killing responsible leadership. Journal of Management Development, 31(5), 470-487.

Kets de Vries, M. (2003). Leaders, Fools and Imposters: Essays on the Psychology of Leadership. Fountainbleu: iUniverse.

Kets de Vries, M. (2005). Leadership coaching in action: The Zen of creating high performance teams. Academy of Management Executive, 19(1), 61-76.

Khoo, H. S., \& Burch, G. S. J. (2008). The "Dark side" of leadership personality and transformational leadership: An exploratory study. Personality and Individual Differences, 44(1), 86-97.

Ladkin, D., \& Spiller, C. (2013). Authentic Leadership: Clashes, Convergences and Coalescences. Cheltenham, UK.: Edward Elgar.

Ladkin, D., \& Taylor, S. S. (2010). Enacting the "true self": Towards a theory of embodied authentic leadership. The Leadership Quarterly, 21(1), 64-74.

Lawler, J., \& Ashman, I. (2012). Theorizing leadership authenticity: A Sartrean perspective. Leadership, 8(4), 327-344. 
Luthans, F. (2002). Positive organizational behavior: Developing and managing psychological strengths. Academy of Management Executive, 16(1), 57-72.

Maslow, A. H. (1950). Self-actualizing people: A Study of psychological health. Personality, Symposium , 11-34.

Neumann, J., \& Hirschhorn, L. (1999). The Challenge of integrating psychodynamic and organzational theory. Human Relations, 52(6), 683-695.

Nicholson, H., \& Carroll, B. (2013). So you want to be authentic in your leadership: To whom an to what end? In D. Ladkin \& C. Spiller (Eds.), Authentic Leadership: Clashes, Convergences and Coalescences (pp. 286-302). Cheltenham, UK.: Edward Elgar.

Nyberg, D., \& Sveningsson, S. (2014). Paradoxes of authentic leadership: Leader identity struggles. Leadership, 10(4), 437-455.

Poutiatine, M. I. (2009). What is transformation?: Nine principles toward an understanding of the transformational process for transformational leadership. Journal of Transformative Education, 7(3), 189-208.

Rogers, C. (2012). On Becoming A Person: A Therapist's View of Psychotherapy. London/New York: Houghton Mifflin.

Rozuel, C., \& Kakabadse, N. (2010). Ethics, spirituality and self: managerial perspective and leadership implications. Business Ethics: A European Review, 19(4), 423-436.

Sanders, J. E., Hopkins, W. E., \& Geroy, G. D. (2003). From transactional to transcendental: Toward an integrated theory of leadership. Journal of Leadership \& Organizational Studies, 9(4), 21-31.

Shaw, J. (2010). Papering the cracks with discourse: The Narrative identity of the authentic 
leader. Leadership, 6(1), 89-108.

Silvia, P. J., \& Duval, T. S. (2001). Objective self-awareness theory: Recent progress and enduring problems. Personality and Social Psychology Review, 5, 230-241.

Smolovic Jones, O., \& Grint, K. (2013). Authentic leadership and history. In D. Ladkin \& C. Spiller (Eds.), Authentic Leadership: Clashes, Convergences and Coalescences (pp. 2138). Cheltenham, UK.: Edward Elgar.

Springborg, C. (2012). Perceptual Refinement : Art-based Methods in Managerial Education Perceptual Refinement : Art-based Methods. Organizational Aesthetics, 1(1), 116-137.

Walumbwa, F. O., Avolio, B. J., Gardner, W. L., Wernsing, T. S., \& Peterson, S. J. (2008). Authentic Leadership: Development and Validation of a Theory-Based Measure: Journal of Management, 34(1), 89-126.

Wilson, T. D. (2004). Strangers to Ourselves. Cambridge MA: Harvard University Press.

Young, J. (2002). A Spectrum of consciousness for CEOs: A Business application of Ken Wilbur's spectrum of consciousness. The International Journal of Organizational Analysis, 10(1), 30-54. 